AperTO - Archivio Istituzionale Open Access dell'Università di Torino

\title{
Precision medicine in ALK rearranged NSCLC: A rapidly evolving scenario
}

\section{This is the author's manuscript}

Original Citation:

Availability:

This version is available http://hdl.handle.net/2318/1656373

since 2018-08-27T13:36:30Z

Published version:

DOI:10.1016/j.critrevonc.2017.12.015

Terms of use:

Open Access

Anyone can freely access the full text of works made available as "Open Access". Works made available under a Creative Commons license can be used according to the terms and conditions of said license. Use of all other works requires consent of the right holder (author or publisher) if not exempted from copyright protection by the applicable law. 


\section{Accepted Manuscript}

Title: Precision medicine in ALK rearranged NSCLC: A rapidly evolving scenario

Authors: Addeo Alfredo, Tabbò Fabrizio, Robinson Tim, Buffoni Lucio, Novello Silvia

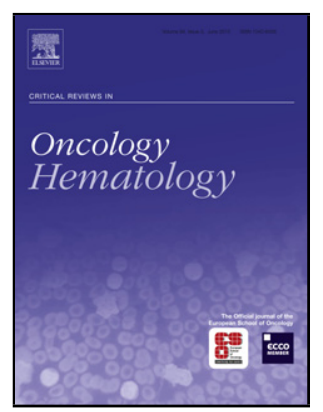

PII:

S1040-8428(17)30485-7

DOI: https://doi.org/10.1016/j.critrevonc.2017.12.015

Reference: ONCH 2479

To appear in: Critical Reviews in Oncology/Hematology

Received date: 30-10-2017

Revised date: $18-12-2017$

Accepted date: 20-12-2017

Please cite this article as: Alfredo Addeo, Fabrizio Tabbò, Tim Robinson, Lucio Buffoni, Silvia Novello.Precision medicine in ALK rearranged NSCLC: A rapidly evolving scenario.Critical Reviews in Oncology and Hematology https://doi.org/10.1016/j.critrevonc.2017.12.015

This is a PDF file of an unedited manuscript that has been accepted for publication. As a service to our customers we are providing this early version of the manuscript. The manuscript will undergo copyediting, typesetting, and review of the resulting proof before it is published in its final form. Please note that during the production process errors may be discovered which could affect the content, and all legal disclaimers that apply to the journal pertain. 
Precision medicine in ALK rearranged NSCLC: a rapidly evolving scenario

Authors:

Addeo Alfredo ${ }^{1} \mathrm{MD}$, Tabbò Fabrizio² MD PhD, Robinson Tim³ ${ }^{3}$ Buffoni Lucio ${ }^{2} \mathrm{MD}$, Novello Silvia ${ }^{2} \mathrm{MD}$ $\mathrm{PhD}$

Affiliations;

1) Oncology department, University Hospital Geneva, Rue Gabrielle-Perret-Gentil 4, Geneva (CH)

2) Oncology Department, San Luigi Hospital university of Turin, Orbassano, Turin (Italy)

3) Oncology Department, Bristol University Hospital Trust, Horfield Road, Bristol (UK)

Corresponding Author: Alfredo Addeo

Email address : alfredo.addeo76@gmail.com

1) Oncology department, University Hospital Geneva, Rue Gabrielle-Perret-Gentil 4, 1205 Geneva (CH)

Tel: +447593550707

Introduction

Deeper understanding of the pathobiology of non-small cell lung cancer (NSCLC) has led to the development of small molecules that target genetic mutations known to play critical roles in the progression to metastatic disease. Mutations in epidermal growth factor receptor (EGFR), kirsten ras sarcoma oncogene (KRAS) and anaplastic lymphoma kinase ( $A L K)$ translocations are generally mutually exclusive in patients with NSCLC and the presence of one alteration in lieu of another can influence responses to targeted therapy. Thus, testing for these mutations and tailoring therapy accordingly is widely accepted as standard practice ${ }^{1,2,3}$. 
ALK gene rearrangement in NSCLC was identified for the first time in a resected adenocarcinoma specimen from a 62-year-old male smoker. Rearrangements, either inversions or translocations, characterize the genomic disruptions involving $A L K$ observed in NSCLC ${ }^{4,5}$. Inversions in the short arm of chromosome 2 that juxtapose echinoderm microtubule-associated protein-like 4 (EML4) with $A L K$ and produce $E M L 4-A L K$-fusion tyrosine kinases ${ }^{4,6}$ are the most common noted changes but at least 27 fusion variants have been identified ${ }^{7}$. The reported prevalence of $A L K$ rearrangements in unselected NSCLC is approximately $5 \%{ }^{8,9}$. Remarkably, tumors with $A L K$ rearrangements are addicted to ALK signalling and are inhibited by ALK Tyrosine Kinase Inhibitors (TKIs) in preclinical models ${ }^{10,11,12}$.

In the past years several ALK inhibitors (ALKi) have been developed and become widely available in clinical practice; they are listed in table 1 with indication/approval along with the registration trials. Despite the efficacy of all these drugs, all ALK+ lung cancer patients will inevitably progress at some point during their treatment. To date, we are aware of two major mechanisms of resistance: ALKdependent (primary resistance, secondary acquired mutations, gene amplification) and ALKindependent (by-pass signalling, drug efflux pump, epithelial-to-mesenchymal transition). Mechanisms of primary resistance are poorly understood and the spectrum of known secondary mutations mirrors Chronic Myeloid Leukemia (CML) and its mutational landscape acquired during imatinib treatment ${ }^{13}$.

Unfortunately, the initial clinical response to targeted kinase inhibitors is almost always temporary, as acquired resistance to these drugs invariably develops. Many mechanisms of resistance to each targeted therapy have been identified, but can be generally categorized into two predominant classes: (1) alteration of the driver oncogene, (2) activation of a critical signalling pathway(s) in a parallel or downstream fashion, driving pro-survival signalling through different pathways.

The most common and well established mechanism of resistance for the EGFR is the alteration of the driver oncogene, where the gatekeeper T790M mutation is found in $\sim 50 \%$ of EGFR-mutant patients who become resistant to EGFR inhibition ${ }^{14,15}$ This has led to the development of several third-generation EGFR inhibitors, that could potentially block the growth of EGFR T790M-positive tumors ${ }^{16,17,18}$

Unlike EGFR, type and frequency of ALK resistant mutations changes based on the inhibitor class. In crizotinib-refractory patients the most frequent mutations are L1196M and G1269A. The first is a classical gatekeeper mutation that alters the catalytic domain and causes resistance to ATPcompetitive inhibitors $^{19}$, as in EGFR-T790M+ lung cancers. The latter, G1269A, determines a steric hindrance impairing the proper binding of crizotinib ${ }^{20}$. A plethora of less frequent mutations have been also described such as C1156Y, L1152R, 1151 T-ins at the N-terminus domain, I1171T, F1174L near the activation loop and G1202R, S1206Y in the solvent-exposed region close by the crizotinib binding-site $e^{21,22,23,24}$. Patients progressing on crizotinib treatment, regardless the presence of acquired mutations or not, seemed to be still ALK-dependent, as they respond to next-generation inhibitors, probably due to the limited ALK-blockade potency of crizotinib ${ }^{25}$.

In large biopsies series from ALK+ NSCLC treated patients, the number of detected mutations increased after second generation $\mathrm{ALKi}^{26}$ and in one study were present in $56 \%$ of the entire cohort. ${ }^{42}$ For example, the rate of G1202R mutations increases from $2 \%$ in post-crizotinib treated patients to $43 \%$ in post-brigatinib cases highlighting a specific mutational profile associated to each 
ALK TKI. The C1156Y mutation is less efficiently inhibited by ceritinib, contrary to the $11171 T^{41}$ mutation, identified in post-alectinib samples, that results sensitive to ceritinib. The gatekeeper mutation L1196M is inhibited by alectinib but emerges as a post-alectinib mutation itself; F1174L mutations determine resistance to ceritinib but are still sensitive to alectinib; the G1202R, most common mechanism of resistance post-second-generation ALKi (ceritinib, alectinib, brigatinib), is efficiently inhibited only by the third generation compound, lorlatinib, in preclinical models and patients ${ }^{42}$. This scenario becomes even more complex if we add the presence of compound-related resistance mutations that emerge in patients treated with sequential ALK inhibitors: tumor clones harbouring E1210K/D1203N mutations after crizotinib and brigatinib remains sensitive only to lorlatinib ${ }^{42}$; on the other hand, a double mutant patient (C1156Y/L1198F) resistant to crizotinib, ceritinib and lorlatinib appeared to regain sensitivity to crizotinib, with a durable response ${ }^{27}$.

If ALK gene amplification has been identified as resistance mechanism only in a small fraction (9\%) of crizotinib refractory cases, multiple by-pass signalling tracks, which account for $\approx 40 \%$ of nonmutated patients refractory to second-generation $\mathrm{ALKi}^{28}$, have been described: EGFR and HER family members activation ${ }^{29}$, also triggered by paracrine stimuli ${ }^{30}$, MET amplification [19], activation of downstream signalling pathway (i.e. RAS-MEK), even by specific MAP2K1 mutation that makes cancer cells sensitive to ALK/MEK co-inhibition ${ }^{31}$, c-KIT amplification requiring SCF [6], IGF-1R upregulation $^{32}$ SRC activation ${ }^{47}$ and engagement of P2Y receptors ${ }^{33}$. Notably, efflux (MDR1 encoded) pump over-expression may be considered an alternative mechanism of resistance, as demonstrated in patients treated with crizotinib and ceritinib ${ }^{34}$, whose CNS penetration is hindered compared to alectinib that is not a substrate of this drug efflux system.

Lastly, transition to a mesenchymal phenotype represents an alternative escape strategy. EMT has been described in post-ceritinib samples ${ }^{42}$ although the real contribution and underlying molecular mechanisms have not been elucidated yet. Some hypothesis came from the similar scenario of EMT in EGFR-mutant NSCLC in which alternative activation of AXL, IGF-1R or the SRC/FAK pathways have been proposed as causative molecular events ${ }^{35,36,37}$.

\section{ALKi testing, sequencing and best strategies}

The general consensus of the ATLAS IALSC Guidelines ${ }^{38}$ is that screening for ALK gene rearrangement should be performed for all patients with advanced NSCLC, mainly adenocarcinoma or with adenocarcinoma component. Depending on resources and academic interest, screening of patients with advanced NSCLC of other histologies should be considered, especially patients with one or more of these features: younger patient age, never/light smoking history, or negative results on testing for EGFR and KRAS mutations. ALK gene rearrangement may be found in tumors with nonadenocarcinoma histologies, although this finding is rare ${ }^{39,40}$. 
A re-biopsy at progression remains a practice extremely heterogeneous and not completely codified despite the fact that, if a secondary mutation is identified at progression, the tumour should be considered still ALK-dependent and the appropriate ALKi (figure 1) offered, based on the mutational sensitivity. This approach might give the opportunity to further control the cancer, delaying the use of the standard chemotherapy.

It appears evident that the therapeutic landscape has been rapidly evolving and the future of ALK+ NSCLC treatment is promising with multiple therapeutic options over the past years as summarised in table 1.

Crizotinib was the first ALK inhibitor that showed a benefit over the standard chemotherapy treatment in term of increased PFS in the second line setting, compared to chemotherapy in the Profile $1007^{41}$ and in first line setting $n$ the Profile $1014^{42}$ compared to standard platinum based chemotherapy.

Subsequently a different Alk inhibitor, Ceritinib, was developed and tested in several trails either in first line, similarly to the Profile $1014^{42}$ design, within the Ascend $4^{43}$ where ceritinib proved to be superior in term of PFS compared to the standard first line chemotherapy treatment, either after progression to chemotherapy and to crizotinib in the Ascend $5^{44}$

Notably J-Alex trial first ${ }^{45}$ and the Alex trial ${ }^{46}$ later have showed the superiority of alectinib over crizotinib in term of PFS and time to central nervous system (CNS) progression in first line for this group of patients

The J-ALEX trial, the first randomized phase III trial to directly compare two ALK inhibitors (alectinib versus crizotinib) in the first line setting ${ }^{41}$, was conducted exclusively in Japan at 41 study sites between November 2013 and August 2015 and 207 patients with stage IIIB/IV ALK positive NSCLC, who had previously received 0-1 lines of chemotherapy, but no prior ALK TKI, were enrolled and randomized to alectinib $300 \mathrm{mg}$ twice daily or crizotinib $250 \mathrm{mg}$ twice daily. At the time of planned interim analysis, median PFS was not reached in the alectinib arm (20.3 months at the low end of the $\mathrm{Cl}$ ) and was 10.2 months in the crizotinib arm (HR 0.34, 99.7\% $\mathrm{Cl} 0.17-0.70)$. The ORR of alectinib in the intention to treat population was $85.4 \%$ (95\% Cl 78.6-92.3) versus $70.2 \%$ (95\% Cl 61.4-79) in the crizotinib arm. In the subgroup of patients with brain metastasis, there was also a strikingly improved response to alectinib ( $\mathrm{HR} 0.08,95 \% \mathrm{Cl} 0.01-0.61$ ). For patients with brain metastatic lesions at baseline, the HR for the time to progression of a brain metastatic lesion or death was 0.16 (95\% $\mathrm{Cl} \mathrm{0.02-1.28),} \mathrm{and} \mathrm{for} \mathrm{patients} \mathrm{without} \mathrm{brain} \mathrm{metastatic} \mathrm{lesions} \mathrm{at} \mathrm{baseline,} \mathrm{the} \mathrm{HR} \mathrm{for} \mathrm{the} \mathrm{time}$ to onset of a brain metastatic lesion or death was 0.41 (95\% Cl 0.17-1.01). All grade adverse events favored alectinib with the most common side effects in the alectinib arm.

The results of this study were considered certainly compelling with some possible drawbacks: relatively large percentage of patients pre-treated with chemotherapy and a significantly larger percentage of patients with brain metastasis in the crizotinib arm compared to the alectinib one.

The ALEX trial results were presented at ASCO 2017 with simultaneous publication in June 2017. It was an international phase III trial launched across 161 locations in 31 countries, with 303 treatment naïve ALK positive metastatic NSCLC patients randomized to alectinib $600 \mathrm{mg}$ twice daily or crizotinib 250 mg twice daily, with PFS again being the primary endpoint ${ }^{42}$. Secondary endpoints included time 
to CNS progression, ORR, DOR, OS, quality of life, and safety. After a follow up of 17.6 months in the crizotinib arm and 18.6 months in the alectinib arm, median PFS was not reached in the alectinib arm versus 11.1 months with crizotinib (HR 0.47, 95\% Cl 0.34-0.67, $\mathrm{P}<0.001$ ). The effect was seen across nearly all subgroups with the exception of smokers and patients with an ECOG of 2, though these represented small numbers of patients. Time to CNS progression was also significantly longer with alectinib, with a 12-month incidence rate of CNS progression of 9.4\% (95\% Cl 5.4-14.7) with alectinib versus $41.4 \%(95 \% \mathrm{Cl} 33.2-49.4)$ in the crizotinib arm. Among those patients with measurable CNS metastasis at baseline, $81 \%$ (95\% Cl 58-95) had a response in the alectinib arm versus $50 \%(95 \% \mathrm{Cl} 28-72)$ in the crizotinib arm, with $38 \%$ in the alectinib arm having achieved a complete response.

The Alex trial was slightly different from the J-Alex: the study population included patients from multiple countries, the dose of alectinib used was $600 \mathrm{mg}$ twice daily, all the patients were treatment naive, whereas those in the J-ALEX trial could have received chemotherapy initially. However the results of both trials closely mirrored each other and clearly demonstrated that in the frontline setting, alectinib is superior to crizotinib in terms of PFS, ORR, CNS response, and tolerability.

Could we conclude, based on the evidence we have so far, that alectinib should be regarded as the new standard of care in first line or a sequential approach consisting of crizotinib first followed by alectinib could still be a preferable option? Despite the fact that the OS data for both, J Alex and Alex trial, are not yet available, the magnitude of PFS benefit seems to suggest that using the more active drug, alectinib, up front could guarantee a better outcome particularly for its CNS activity and efficacy.

Furthermore several ALKi (lorlatinib ${ }^{47}$, brigatinib ${ }^{48}$ ) have recently showed impressive results on naive and pre-treated ALK+ NSCLC patients increasing the number of therapeutical option available other than crizotinib in phase I-II trials. Thus, if the first line treatment seems to be relatively clear, the question "What to do next?" has become more than ever important and defining the optimal treatment strategy is the new task for the scientific community, even more than developing new ALKi. In the contest of correct sequencing, even if in a different clinical and genomic scenario, a possible answer might come from the APPLE-EORTC1603 trial $^{49}$ : a randomized, open-label, multicenter, 3-arm, phase II study in advanced, EGFR-mutant and EGFR-TKI-naive NSCLC patients, to evaluate the best strategy for sequencing gefitinib and osimertinib treatment. In all arms, a plasmatic ctDNA T790M test will be performed and the primary objective will be to evaluate the best strategy for sequencing of treatment with gefitinib and osimertinib in advanced NSCLC patients with common EGFR mutations, and to understand the value of liquid biopsy for the decision-making process. Even if on a different contest, the EGFR mutated patients, the result might point out that using the most effective TKI, based exclusively on the increased PFS, might not be the best strategy and that sequencing carefully and properly the different and extremely active TKIs has to be carefully considered and it might offer a longer OS in the end.

Although ongoing and future trials will be trying to establish the correct sequencing, we'd want to propose, based on the drugs development, the knowledge on mechanisms of primary and secondary resistance mutations that we already have, a possible treatment algorithm for ALK rearranged NCSLC 
patients (figure1) stratified according to mutations detected throughout their clinical story by serial tissue or liquid biopsies performed at progression.

Upfront and at relapse TKI combination might represent a valid strategy to delay or counteract, once appeared, ALK-independent by-pass track signalling pathways. Moreover permits to delay on-target resistance mechanisms, reducing the typical clonal pressure of single potent TKI monotherapy, like appearance of compound resistance mutations. Potential augmented toxicities of combined TKI politherapies may represent a major issue, partly curbed by reduced dosages or alternative drug schedules. Different strategies have been considered; EML4-ALK fusion proteins are known client of HSP90 chaperone machinery and therefore ganetespib demonstrated efficient control of ALK+ NSCLC either in presence or absence of ALK secondary mutations [54]. Even if not totally understood, this may be related to the wider HSP9O range of activities; parallel TRK (e.g. HER2) pathways, which sustain ALK+ cancer cells, are targeted by HSP9O and its inhibition contribute to shut down downstream signalling pathways. HSP9Oi alone or in combination with ALKi have been investigated (NCT01752400, NCT01712217). Powerful association of pan-HER and ALK inhibitors, supported by strong preclinical evidences ${ }^{50}$, had been limited by high-grade adverse events . ALK/MEK dual inhibition represents a promising therapeutic tool in order to up-front delay resistance mechanisms and improve response duration [56]. Also, MEK mutations appear in a ceritinib-treated patient and MEK inhibition contributes to disease control. Trametinib/ceritinib association is under evaluation (NCT03087448). MET amplification has been identified as postalectinib resistance mechanism and thus the specific patient responded to crizotinib treatment .

Unfortunately, day to day practise might be, by far, different and more complex than what we have described here. In many European countries and in the United States of America the ALK treatment pathway is guided by labelling system and many ALKi are simply not available (table 2). Other than legislation issues and regulatory limitations, to make our algorithm even more challenging, is the fact that performing a re-biopsy at progression in many countries and institutes is not always possible or straight forward given the lack of staff, funding and facilities. Furthermore, even if the drugs were available, there isn't consensus on the specific mutations to look for at progression, which makes even a re-biopsy possibly academic or not effective as it could be.

At certain point all the ALK+ NSCLC will become ALK-independent and in these cases the patients could not benefit from another ALK inhibitors but standard chemotherapy ${ }^{51}$ or combination strategies ought to be considered.

Future studies investigating alectinib-based combinations are already underway including combination with the programmed cell death ligand 1 (PD-L1) inhibitor atezolizumab and or bevacizumab. Integration with Immunotherapy (IO) seems limited by the fact that ALK+ tumors arose in patients with a low mutational load and PD-L1 and CD8 expressions are underrepresented [58]. Studies of these and other alectinib-based combinations should help to identify new therapeutic strategies that can overcome and even potentially prevent resistance. Patients lacking any traceable alteration or clinical-useful biomarker may be recruited for platinum-pemetrexed chemotherapy since ALK+ NSCLC appeared to be particularly sensitive to these therapies: pemetrexed association with crizotinib is object of current clinical evaluation (NCT02134912). 


\section{Conclusions}

Despite the improvement in the knowledge of resistance mechanisms and the efficacy of several ALKi, there are still hurdles to overcome: drug costs and/or local legislation narrow and limit the treatment option for this group of patients. Stronger collaborations between academia, pharmaceutical companies and regulatory authorities need to be spurred to implement availability and affordability of such drugs.

Clinical trials are warranted to further investigate ALKi sequencing with a great interest to the EORTC 1603 trial, to further understand the emerging resistance mechanisms after first-line alectinib and to develop possible strategies for delaying and overcoming these mechanisms.

In conclusion we have summarized the evolution and improvement of ALK+ NSCLC patients treatment and highlighted, in this group of patients, a possible customized strategy, which would be potentially applicable and would represent a step towards personalized medicine.

Table 1 (ALKi trials)

\begin{tabular}{|c|c|c|c|c|c|c|c|c|}
\hline $\begin{array}{l}\text { Drug } \\
\text { name }\end{array}$ & Study & Phase & Population & vs & ORR & IC-ORR & PFS & OS \\
\hline Crizotinib & $\begin{array}{l}\text { PROFILE } \\
1007\end{array}$ & III & $\begin{array}{l}\text { Platinum- } \\
\text { based } \\
\text { chemotherapy } \\
\text { pretreated } \\
(n=347)\end{array}$ & $\begin{array}{l}\text { Pemetrexed } \\
\text { or docetaxel }\end{array}$ & $\begin{array}{l}65 \%(95 \% \\
\text { CI } 58- \\
72 \%) \\
\text { versus } \\
20 \%(95 \% \\
\text { CI } 14- \\
26 \% ;\end{array}$ & NA & $\begin{array}{l}7.7 \quad \text { versus } \\
3.0 \text { months } \\
(\mathrm{HR}, \quad 0.49 \\
95 \% \quad \text { CI } \\
0.37-0.64 ; \\
p<0.001)\end{array}$ & $\begin{array}{l}20.3 \quad(95 \% \\
\text { CI } 18.1-\text { not } \\
\text { reached) } \\
\text { versus } 22.8 \\
\text { months } \\
(95 \% \text { CI } \\
18.6 \text {-not }\end{array}$ \\
\hline
\end{tabular}




\begin{tabular}{|c|c|c|c|c|c|c|c|c|}
\hline & & & & & $p<0.001)$ & & & $\begin{array}{l}\text { reached) } \\
(\mathrm{HR}, 1.02 ; \\
95 \% \quad \mathrm{CI} \\
0.68-1.54 ; \\
p=0.54)\end{array}$ \\
\hline Crizotinib & $\begin{array}{l}\text { PROFILE } \\
1014\end{array}$ & III & $\begin{array}{l}\text { Previously } \\
\text { untreated } \\
(n=343)\end{array}$ & $\begin{array}{l}\text { Platinum } \\
\text { plus } \\
\text { pemetrexed }\end{array}$ & $\begin{array}{l}74 \%(95 \%) \\
\text { CI } \quad 67- \\
81 \%) \\
\text { versus } \\
45 \%(95 \% \\
\text { CI } \quad 37- \\
53 \% \text {; } \\
p<0.001)\end{array}$ & NA & $\begin{array}{l}10.9 \text { versus } \\
7.0 \text { months } \\
(\mathrm{HR}, 0.45 \\
95 \% \quad \mathrm{CI} \\
0.35-0.60 \\
p<0.001\end{array}$ & $\begin{array}{l}\text { Median } \\
\text { was not } \\
\text { reached in } \\
\text { either group } \\
\text { (HR for } \\
\text { death with } \\
\text { crizotinib, } \\
0.82 ; \quad 95 \% \\
\text { CI } 0.54- \\
\begin{array}{l}1.26 ; \\
p=0.36)\end{array}\end{array}$ \\
\hline Ceritinib & $\begin{array}{l}\text { ASCEND } \\
4\end{array}$ & III & $\begin{array}{l}\text { Previously } \\
\text { untreated } \\
(\mathrm{n}=376)\end{array}$ & $\begin{array}{l}\text { Platinum } \\
\text { plus } \\
\text { pemetrexed }\end{array}$ & $\begin{array}{l}(72 \cdot 5 \% \\
{[95 \% \quad \text { CI }} \\
65 \cdot 5- \\
78 \cdot 7]) \quad \text { vs } \\
(26 \cdot 7 \% \\
{[20 \cdot 5-} \\
33 \cdot 7])\end{array}$ & $\begin{array}{l}72.7 \% \text { vs } \\
27 \%\end{array}$ & $\begin{array}{l}16.6 \text { vs } 8.1 \\
\text { months } \\
(\mathrm{HR} \\
0.49 ; 95 \% \\
0 \cdot 37-0 \cdot 64] \\
\text { p<0.00001 }\end{array}$ & NA \\
\hline Ceritinib & $\begin{array}{l}\text { ASCEND } \\
5\end{array}$ & III & $\begin{array}{l}\text { Platinum- } \\
\text { based } \\
\text { chemotherapy } \\
\text { and crizotinib } \\
\text { pretreated } \\
(\mathrm{n}=231)\end{array}$ & $\begin{array}{l}\text { Pemetrexed } \\
\text { or docetaxel }\end{array}$ & $\begin{array}{l}39 \% \quad \mathrm{vs} \\
7 \%\end{array}$ & $\begin{array}{l}35 \% \quad \text { vs } \\
5 \%\end{array}$ & 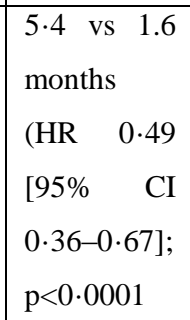 & $\begin{array}{l}18.1 \text { vs } \\
20.1 \\
\text { months not } \\
\text { statistivaly } \\
\text { significant. }\end{array}$ \\
\hline Ceritinib & $\begin{array}{l}\text { ASCEND } \\
8\end{array}$ & I & $\begin{array}{l}3 \text { cohorts (267 } \\
\text { pts in total), } \\
121 \text { treatment } \\
\text { naive }\end{array}$ & $\begin{array}{lll}450 & \mathrm{mg} & \mathrm{vs} \\
600 & \mathrm{mg} & \mathrm{vs} \\
750 & & \mathrm{mg} \\
& & \\
(\mathrm{SOC}) & & \end{array}$ & $\begin{array}{l}78 \%, 75 \% \\
\text { and } 70 \%\end{array}$ & $\mathrm{NA}$ & $\begin{array}{l}15 \text { months } \\
\text { PFS rate } \\
\text { was } 66.4 \% \text {, } \\
58 \% \text { and } \\
41 \% \text {. }\end{array}$ & NA \\
\hline Alectinib & $\begin{array}{l}\text { Global } \\
\text { study }\end{array}$ & II & $\begin{array}{l}\text { Crizotinib } \\
\text { preteated }\end{array}$ & Single arm & $\begin{array}{l}50 \%(95 \% \\
\text { CI, } 41 \% \\
\text { to } 59 \%)\end{array}$ & $50 \%$ & $\begin{array}{l}8.9 \text { months } \\
\text { (95\% CI, } \\
5.6 \text { to } 11.3 \\
\text { months) }\end{array}$ & NA \\
\hline Alectinib & ALEX & III & $\begin{array}{l}\text { Previously } \\
\text { untreated } \\
(\mathrm{n}=303)\end{array}$ & Crizotinib & $\begin{array}{l}82.9 \% \\
(95 \% \quad \text { CI } \\
85 \%- \\
76 \%) \quad \text { vs } \\
75.2(95 \% \\
67.8 \%- \\
82.1 \% \quad \text { p } \\
<0.01)\end{array}$ & $\begin{array}{ll}81 \% & \text { vs } \\
50 \% & \end{array}$ & $\begin{array}{l}25.7 \quad \text { vs } \\
10.4 \\
\text { months } \\
(\mathrm{HR}=0.50, \\
95 \% \quad \mathrm{CI}, \\
0.36-0.70 ; \\
\mathrm{p}<0.0001)\end{array}$ & $\mathrm{NA}$ \\
\hline Alectinib & J-ALEX & III & Previously & Crizotinib & $85 \%(95 \%$ & $80 \%$ & 20.3 & $\mathrm{NA}$ \\
\hline
\end{tabular}




\begin{tabular}{|c|c|c|c|c|c|c|c|c|}
\hline & & & untreated & & $\begin{array}{l}\text { CI } 78 \cdot 6- \\
92 \cdot 3) \quad \text { vs } \\
70 \% \\
(61 \cdot 4- \\
79 \cdot 0 \quad \text { p < } \\
0.01) \quad\end{array}$ & $52 \%$ & $\begin{array}{l}10 \cdot 2 \quad(\mathrm{HR} \\
0 \cdot 3499 \cdot 7 \% \\
\mathrm{CI} \quad 0 \cdot 17- \\
0 \cdot 71, \\
\mathrm{p}<0.0001)\end{array}$ & \\
\hline Brigatinib & $\begin{array}{l}\text { NCT0144 } \\
\underline{9461}\end{array}$ & $\mathrm{I} / \mathrm{II}$ & $\begin{array}{l}\text { Previously } \\
\text { Treated with } \\
\text { crizotinib and } \\
\text { naive } \\
(\mathrm{n}=79)\end{array}$ & $\begin{array}{l}\text { Brigatinib } \\
(30-300 \mathrm{mg})\end{array}$ & $\begin{array}{l}71 \% \text { in } \\
\text { crizotinib- } \\
\text { pretreated } \\
\text { and } 100 \% \\
\text { in } \\
\text { crizotinib- } \\
\text { naive } \\
\text { group }\end{array}$ & $53 \%$ & $\begin{array}{l}13.4 \\
\text { months in } \\
\text { pretreated } \\
\text { crizotinib }\end{array}$ & NA \\
\hline Brigatinib & ALTA & II & $\begin{array}{l}\text { Previously } \\
\text { treated with } \\
\text { crizotinib } \\
\text { and/or } \\
\text { chemotherapy } \\
(\mathrm{n}=222)\end{array}$ & $\begin{array}{l}\text { Brigatinib } 90 \\
\text { g vs } 180 \mathrm{mg}\end{array}$ & $\begin{array}{l}48 \% \\
(90 \mathrm{mg}) \\
53 \% \\
(180 \mathrm{mg})\end{array}$ & $\begin{array}{l}51 \% \text { and } \\
55 \%\end{array}$ & $\begin{array}{l}9.2 \text { and } \\
16.7 \\
\text { months }\end{array}$ & NA \\
\hline Lorlatinib & $\begin{array}{l}\text { NCT0197 } \\
0865\end{array}$ & II & $\begin{array}{l}6 \quad \text { cohorts } \\
\text { including pts } \\
\text { naive (275 in } \\
\text { tot) }\end{array}$ & Lorlatinib & $\begin{array}{l}90 \% \\
\text { (naive) }\end{array}$ & $\begin{array}{l}75 \% \\
\text { (naive) }\end{array}$ & NA & NA \\
\hline Ensartinib & $\begin{array}{l}\text { NCT0276 } \\
7804\end{array}$ & III & NA & Crizotinib & $\mathrm{NA}$ & $\mathrm{NA}$ & $\mathrm{NA}$ & NA \\
\hline $\begin{array}{l}\text { Entrectini } \\
b\end{array}$ & $\begin{array}{l}\text { NCT0209 } \\
7810\end{array}$ & I & NA & NA & NA & NA & NA & NA \\
\hline $\begin{array}{l}\text { TPX- } \\
0005\end{array}$ & $\begin{array}{l}\text { NCT0309 } \\
3116\end{array}$ & I & NA & NA & $\mathrm{NA}$ & NA & NA & NA \\
\hline
\end{tabular}

Table 2 (ALki approval)

\begin{tabular}{|l|l|l|l|l|l|l|}
\hline $\begin{array}{l}\text { Active } \\
\text { ingredient }\end{array}$ & Indication & Selection & Dose & $\begin{array}{l}\text { FDA } \\
\text { approval }\end{array}$ & $\begin{array}{l}\text { EMEA } \\
\text { approval }\end{array}$ & $\begin{array}{l}\text { NICE } \\
\text { approval }\end{array}$ \\
\hline Crizotinib & $\begin{array}{l}\text { ALK+ } \\
\text { metastatic } \\
\text { NSCLC }\end{array}$ & $\begin{array}{l}\text { VENTANA } \\
\text { ALK (D5F3) } \\
\text { CDx Assay } \\
\text { Vysis ALK }\end{array}$ & $250 \mathrm{mg}$ bid & untreated patients & $\begin{array}{l}\text { untreated } \\
\text { patients }\end{array}$ & $\begin{array}{l}\text { untreated } \\
\text { patients }\end{array}$ \\
\hline Ceritinib & $\begin{array}{l}\text { ALK+ } \\
\text { metastatic }\end{array}$ & $\begin{array}{l}\text { VENTANA } \\
\text { ALK (D5F3) }\end{array}$ & $750 \mathrm{mg}$ od & untreated patients & $\begin{array}{l}\text { crizotinib } \\
\text { pretreated }\end{array}$ & $\begin{array}{l}\text { crizotinib } \\
\text { pretreated }\end{array}$ \\
\hline
\end{tabular}




\begin{tabular}{|c|c|c|c|c|c|c|}
\hline & NSCLC & $\begin{array}{l}\text { CDx Assay } \\
\text { Vysis ALK }\end{array}$ & & & patients & patients \\
\hline Alectinib & $\begin{array}{l}\text { ALK+ } \\
\text { metastatic } \\
\text { NSCLC }\end{array}$ & $\begin{array}{l}\text { VENTANA } \\
\text { ALK (D5F3) } \\
\text { CDx Assay } \\
\text { Vysis ALK }\end{array}$ & $600 \mathrm{mg}$ bid & untreated patients & $\begin{array}{l}\text { crizotinib } \\
\text { pretreated } \\
\text { patients }\end{array}$ & $\begin{array}{l}\text { MISSING } \\
\text { (no evidence } \\
\text { submission) }\end{array}$ \\
\hline Brigatinib & $\begin{array}{l}\text { ALK+ } \\
\text { metastatic } \\
\text { NSCLC }\end{array}$ & $\begin{array}{l}\text { VENTANA } \\
\text { ALK (D5F3) } \\
\text { CDx Assay } \\
\text { Vysis ALK }\end{array}$ & $\begin{array}{l}90 \mathrm{mg} \text { od for } \\
\text { the first } 7 \\
\text { days; } \\
\text { if tolerated, } \\
\text { increase to } \\
180 \mathrm{mg} \text { od }\end{array}$ & $\begin{array}{ll}\text { intolerant to } & \text { or } \\
\text { progressing } & \text { on } \\
\text { crizotinib } & \end{array}$ & MISSING & MISSING \\
\hline Lorlatinib & $\begin{array}{l}\text { ALK+ } \\
\text { metastatic } \\
\text { NSCLC }\end{array}$ & $\begin{array}{l}\text { VENTANA } \\
\text { ALK (D5F3) } \\
\text { CDx Assay } \\
\text { Vysis ALK }\end{array}$ & $100 \mathrm{mg}$ od & $\begin{array}{l}\text { Breakthrough } \\
\text { Therapy } \\
\text { designation - } \\
\text { intolerant to or } \\
\text { progressing on } \\
\text { crizotinib }\end{array}$ & MISSING & MISSING \\
\hline Entrectinib & $\begin{array}{l}\text { ALK+ } \\
\text { metastatic } \\
\text { NSCLC }\end{array}$ & $\begin{array}{l}\text { VENTANA } \\
\text { ALK (D5F3) } \\
\text { CDx Assay } \\
\text { Vysis ALK }\end{array}$ & NA & on going & MISSING & MISSING \\
\hline Ensartinib & $\begin{array}{l}\text { ALK+ } \\
\text { metastatic } \\
\text { NSCLC }\end{array}$ & $\begin{array}{l}\text { VENTANA } \\
\text { ALK (D5F3) } \\
\text { CDx Assay } \\
\text { Vysis ALK }\end{array}$ & NA & on going & MISSING & MISSING \\
\hline
\end{tabular}

\section{REFERENCES:}

[1] National Comprehensive Cancer Network. NCCN Clinical Practice Guidelines in Oncology, NonSmall Cell Lung Cancer V7.2015.July 15, 2015

[2] Keedy VL, Temin S, Somerfield MR, et al. American Society of Clinical Oncology provisional clinical opinion: epidermal growth factor receptor (EGFR) Mutation testing for patients with advanced non-small-cell lung cancer considering first-line EGFR tyrosine kinase inhibitor therapy. J Clin Oncol. 2011 May 20. 29(15):2121-7. [Medline]. 
[3] Stella GM, Scabini R, Inghilleri S, Cemmi F, Corso S, Pozzi E, et al. EGFR and KRAS mutational profiling in fresh non-small cell lung cancer (NSCLC) cells. J Cancer Res Clin Oncol. 2013 May 5.

[4] M Soda, YL Choi, M Enomoto, etal: Identification of the transforming EML4-ALK fusion gene in non-small-cell lung cancer Nature 448: 561- 566,2007

[5] MI SA CHE QUESTA E' LA STESSA CITAZIONE DI PRIMA (NUM 4)

[6] SH Ou, CH Bartlett, M Mino-Kenudson, etal: Crizotinib for the treatment of ALK-rearranged nonsmall cell lung cancer: A success story to usher in the second decade of molecular targeted therapy in oncology Oncologist 17: 1351-1375,2012

[7] YL Choi, K Takeuchi, M Soda, etal: Identification of novel isoforms of the EML4-ALK transforming gene in non-small cell lung cancer Cancer Res 68: 4971- 4976,2008

[8] Sasaki T., Rodig S., Chirieac L., Jänne P. (2010) The biology and treatment of EML4-ALK nonsmall cell lung cancer. Eur J Cancer 46: 1773-1780.

[9] K Inamura, K Takeuchi, Y Togashi, etal: EML4-ALK fusion is linked to histological characteristics in a subset of lung cancers J Thorac Oncol 3: 13-17,2008

[10] SJ Rodig, M Mino-Kenudson, S Dacic , etal: Unique clinicopathologic features characterize ALKrearranged lung adenocarcinoma in the Western population Clin Cancer Res 15: 5216- 5223,2009

[11] JG Christensen, HY Zou, ME Arango, etal: Cytoreductive antitumor activity of PF-2341066, a novel inhibitor of anaplastic lymphoma kinase and c-Met, in experimental models of anaplastic largecell lymphoma Mol Cancer Ther 6: 3314- 3322,2007

[12] J Settleman : Cell culture modeling of genotype-directed sensitivity to selective kinase inhibitors: Targeting the anaplastic lymphoma kinase (ALK) Semin Oncol 36: S36- S41,2009

[13] U McDermott, AJ lafrate, NS Gray, etal: Genomic alterations of anaplastic lymphoma kinase may sensitize tumors to anaplastic lymphoma kinase inhibitors Cancer Res 68: 3389- 3395,2008

[14] Von Bubnoff N, Schneller F, Peschel C, Duyster J. "BCR-ABL gene mutations in relation to clinical resistance of Philadelphia-chromo- some-positive leukaemia to STI571: a prospective study." Lancet 2002;359:487-91

[15] Pao, W. et al. Acquired resistance of lung adenocarcinomas to gefitinib or erlotinib is associated with a second mutation in the EGFR kinase domain. PLoS. Med. 2, e73 (2005). 
[16] Ma, C., Wei, S. \& Song, Y. T790M and acquired resistance of EGFR TKI: a literature review of clinical reports. J. Thorac. Dis. 3, 10-18 (2011).

[17] Cross DA, Ashton SE, Ghiorghiu S, Eberlein C, Nebhan CA, Spitzler PJ, Orme JP, Finlay MR, Ward RA, Mellor MJ, Hughes G, Rahi A, Jacobs VN, Red Brewer M, Ichihara E, Sun J, Jin H, Ballard P, Al-Kadhimi K, Rowlinson R, Klinowska T, Richmond GH, Cantarini M, Kim DW, Ranson MR, Pao W. AZD9291, an irreversible EGFR TKI, overcomes T790M-mediated resistance to EGFR inhibitors in lung cancer. Cancer Discov. 2014;4(9):1046-61.

[18] Walter AO, Sjin RT, Haringsma HJ, Ohashi K, Sun J, Lee K, Dubrovskiy A, Labenski M, Zhu Z, Wang Z, Sheets M, St Martin T, Karp R, van Kalken D, Chaturvedi P, Niu D, Nacht M, Petter RC, Westlin W, Lin K, Jaw-Tsai S, Raponi M, Van Dyke T, Etter J, Weaver Z, Pao W, Singh J, Simmons AD, Harding TC, Allen A. Discovery of a mutant-selective covalent inhibitor of EGFR that overcomes T790M-mediated resistance in NSCLC. Cancer Discov. 2013;3(12):1404-15.

[19] Park K, Lee J-S, Lee KH, Kim J-H, Min YJ, Cho JY, Han J-Y, Kim B-S, Kim J-S, Lee DH, Kang JH, Cho EK, Jang I-J, Jung J, Kim H-Y, Sin HJ, Son J, Woo JS, Kim D-W. Updated safety and efficacy results from phase I/II study of HM61713 in patients (pts) with EGFR mutation positive nonsmall cell lung cancer (NSCLC) who failed previous EGFR-tyrosine kinase inhibitor (TKI). ASCO Meet Abstr. 2015;33(15):8084

[20] Young Lim Choi, M.D., et al for the ALK Lung Cancer Study Group "EML4-ALK Mutations in Lung Cancer That Confer Resistance to ALK Inhibitors" NEJM 2010; 363:1734-1739October 28, 2010

[21] Robert C. Doebele, Amanda B. et al "Mechanisms of Resistance to Crizotinib in Patients with ALKGene Rearranged Non-Small Cell Lung Cancer. Clin cancer research March 2012 Volume 18, Issue 5

[22] Takaaki Sasaki, Jussi Koivunen et al "A novel ALK secondary mutation and EGFR signalling cause resistance to ALK kinase inhibitors". Cancer research 2011 sept 15

[23] Ryohei Katayama, Alice T. Shaw ${ }^{1}$; Tahsin M. Khan et al Mechanisms of Acquired Crizotinib Resistance in ALK-Rearranged Lung Cancers. Science Translational Medicine 08 Feb 2012: Vol. 4, Issue 120, pp. 120ra17

[24] Gouji Toyokawa, Fumihiko Hirai et al "Secondary Mutations at I1171 in the ALK Gene Confer Resistance to Both Crizotinib and Alectinib" JThorOncol December 2014Volume 9, Issue 12, Pages e86-e87 
[25] Ryohei Katayama, Tahsin M. Khan et al "Therapeutic strategies to overcome crizotinib resistance in non-small cell lung cancers harboring the fusion oncogene EML4-ALK"Proc Natl acad Sci USA 2011 May, 3:108;753-7540

[26] Sai-Hong Ignatius Ou, MD, PhD, Samuel J. Klempner, MD, Joel R. Greenbowe, BS, Michele Azada et al "Next-Generation Sequencing Reveals a Novel NSCLC ALK F1174V Mutation and Con rms ALK G1202R Mutation Confers High-Level Resistance to Alectinib in ALK-Rearranged NSCLC Patients Who Progressed on Crizotinib “.JThor Onc, Volume 9, Number 12, December 2014

[27] Gainor JF, Dardaei L, Yoda S, Friboulet L, Leshchiner I, Katayama R, et al. Molecular mechanisms of resistance to first- and second- generation ALK inhibitors in ALK-rearranged lung cancer. Cancer Discov 2016;6:1118-33.

[28] Shaw AT, Friboulet L, Leshchiner I, Gainor JF, Bergqvist S, Brooun A, et al. "Resensitization to crizotinib by the lorlatinib ALK resistance mutation L1198F". N Engl J Med 2016;374:54-61.

[29] Tabbo' F, Pizzi m, et al “ Oncogenic kinase fusions: an evolving arena with innovative clinical opportunities" Oncotarget. 2016 May 3; 7(18): 25064-25086

[30] Se Hoon Choi, Dong Ha Kim, Yun Jung Cho, Seon Ye Kim, Jung-Eun Lee, Ki Jung Sung, Woo Sung Kim, Chang-Min Choi, Jin Kyung Rho and Jae Cheol Lee "Multiple receptor tyrosine kinase activation related to ALK inhibitor resistance in lung cancer cells with ALK rearrangement" Oncotarget May 08, 2017

[31]

Tadaaki Yamada, Shinji Takeuchi, Junya Nakade, Kenji Kita, Takayuki Nakagawa, Shigeki Nanjo, Ta kahiro Nakamura, Kunio Matsumoto, Manabu Soda, Hiroyuki Mano, Toshimitsu Uenaka and Seiji Yan "Paracrine Receptor Activation by Microenvironment Triggers Bypass Survival Signals and ALK Inhibitor Resistance in EML4-ALK Lung Cancer Cells" Clinical cancer research July 2012 Volume 18, Issue 13

[32] Crystal AS, Shaw AT, Sequist LV, Friboulet L, Niederst MJ, Lock- erman EL, et al. Patientderived models of acquired resistance can identify effective drug combinations for cancer. Science 2014;346:1480-6.

[33] Lovly CM, McDonald NT, Chen H, Ortiz-Cuaran S, Heukamp LC, Yan Y, et al. Rationale for cotargeting IGF-1R and ALK in ALK fusion-positive lung cancer. Nat Med 2014;20:1027-34

[34] Frederick H. Wilson, Cory M. Johannessen, Federica Piccioni et al « A Functional Landscape of Resistance to ALK Inhibition in Lung Cancer"Cancer cell Volume 27, Issue3, p397-408, 9 March 2015 
[35] Katayama R, Sakashita T, Yanagitani N, Ninomiya H, Horiike A, Friboulet L, et al. P-glycoprotein mediates ceritinib resistance in anaplastic lymphoma kinase-rearranged non-small cell lung cancer. EBioMedicine 2015;3:54-66

[36] Zhang Z, Lee JC, Lin L, Olivas V, Au V, LaFramboise T, et al. Activa- tion of the AXL kinase causes resistance to EGFR-targeted therapy in lung cancer. Nat Genet 2012;44:852-60

[37] Zhou J, Wang J, Zeng Y, Zhang X, Hu Q, Zheng J, et al. Implication of epithelial-mesenchymal transition in IGF1R-induced resistance to EGFR-TKIs in advanced non-small cell lung cancer. Oncotarget 2015;6:44332-45

[38] Wilson C, Nicholes K, Bustos D, Lin E, Song Q, Stephan JP, et al. Overcoming EMT-associated resistance to anti-cancer drugs via Src/ FAK pathway inhibition. Oncotarget 2014;5:7328-41 [39] ATLAS IALSC of ALK and ROS1 testing in Lung cancer, $2^{\text {nd }}$ edition 2017.

[40] Soda M, Choi YL, Enomoto M, Takada S, et al. Identification of the transforming EML4-ALK fusion gene in non-small-cell lung cancer. Nature. 2007 Aug 2;448(7153):561-6. Epub 2007 Jul 11.

[41] Caliò A, Nottegar A, Gilioli E, Bria E, Pilotto et al. ALK/EML4 fusion gene may be found in pure squamous carcinoma of the lung. J Thorac Oncol. 2014 May;9(5):729-32. doi: 10.1097/JTO.0000000000000109.

[42] Shaw AT, Kim DW, Nakagawa K, Seto T, Crinó L, Ahn MJ, De Pas T, Besse B, Solomon BJ, Blackhall F, Wu YL, Thomas M, O'Byrne KJ, Moro-Sibilot D, Camidge DR, Mok T, Hirsh V, Riely GJ, lyer S, Tassell V, Polli A, Wilner KD, Jänne PA. Crizotinib versus chemotherapy in advanced ALK-positive lung cancer. NEJM 2013 Jun 20;368(25):2385-94. doi: 10.1056/NEJMoa1214886. Epub 2013 Jun 1.

[43] Shaw $A T^{1}$, Kim DW, Nakagawa K, Seto T, Crinó L et al. Crizotinib versus chemotherapy in vanced ALK-positive lung cancer. N Engl J Med. 2013 Jun 20;368(25):2385-94. doi:

10.1056/NEJMoa1214886. Epub 2013 Jun 1.

[44] Soria JS, Daniel S W Tan, MD, Rita Chiari,Prof Yi-Long Wu, Prof Luis Paz-Ares et al. First-line ceritinib versus platinum-based chemotherapy in advanced ALK-rearranged non-small-cell lung cancer (ASCEND-4): a randomised, open-label, phase 3 study. Lancet Oncology V 389, N10072 p917-929 march 2017

[45] Shaw A.T, Kim T.M, Crinò L, Gridelli C et al. Ceritinib versus chemotherapy in patients with ALKrearranged non-small-cell lung cancer previously given chemotherapy and crizotinib (ASCEND-5): a randomised, controlled, open-label, phase 3 trial. Lancet Oncology Vol 18, N7 pag 874-886 July 2017 
[46] Toyoaki Hida, Hiroshi Nokihara, Masashi Kondo et al Alectinib versus crizotinib in patients with ALK-positive non-small-cell lung cancer (J-ALEX): an open-label, randomised phase 3 trial. Lancet Onc Volume 390, p29-39, 1 July 2017

[47] Peters S, Camidge R, Shaw AT, Gadgeel S, Ahn J, et al. Alectinib versus Crizotinib in Untreated ALK-Positive Non-Small-Cell Lung Cancer. NEJM une 6, 2017DOI: 10.1056/NEJMoa1704795

[48] Alice Tsang Shaw, Sai-Hong Ignatius Ou, Enriqueta Felip, Todd Michael Bauer, Benjamin Besse, Shirish M. Gadgeel, Efficacy and safety of lorlatinib in patients (pts) with ALK+ non-small cell lung cancer (NSCLC) with one or more prior ALK tyrosine kinase inhibitor (TKI): A phase I/II study. DOI:10.1200/JCO.2017.35.15_suppl.9006Journal of Clinical Oncology 35, no. 15 suppl_(May 2017)

[49] Dong-Wan Kim, Marcello Tiseo, Myung-Ju Ahn, Karen L. Reckamp, Karin Holmskov Hansen, Sang-We Kim. Brigatinib in Patients With Crizotinib-Refractory Anaplastic Lymphoma Kinase-Positive Non-Small-Cell Lung Cancer: A Randomized, Multicenter Phase II Trial. JCO n0 22 (August 2017) 2490-2498

[50] RemonJ, Menis J, Hasan B, Peric A, DeMaio E, Novello S et al. The APPLE Trial: Feasibility and Activity of AZD9291 (Osimertinib) Treatment on Positive PLasma T790M in EGFR-mutant NSCLC Patients. EORTC 1613

[51] Vaishnavi A, Schubert L, Rix U, Marek L et al. EGFR Mediates Responses to Small-Molecule Drugs Targeting Oncogenic Fusion Kinases. Cancer research DOI: 10.1158/0008-5472.CAN-170109 Published July 2017

[52] Park S, Park TS, Choi CM, Lee DH, Kim SW, Lee JS, Kim WS, Song JS, Lee JC. Survival benefit of pemetrexed in lung adenocarcinoma patients with anaplastic lymphoma kinase gene rearrangements. Clin Lung Cancer. 2015;16:e83-e89. doi: 10.1016/j.cllc.2015.01.003

Figure 1(treatment flowchart) 


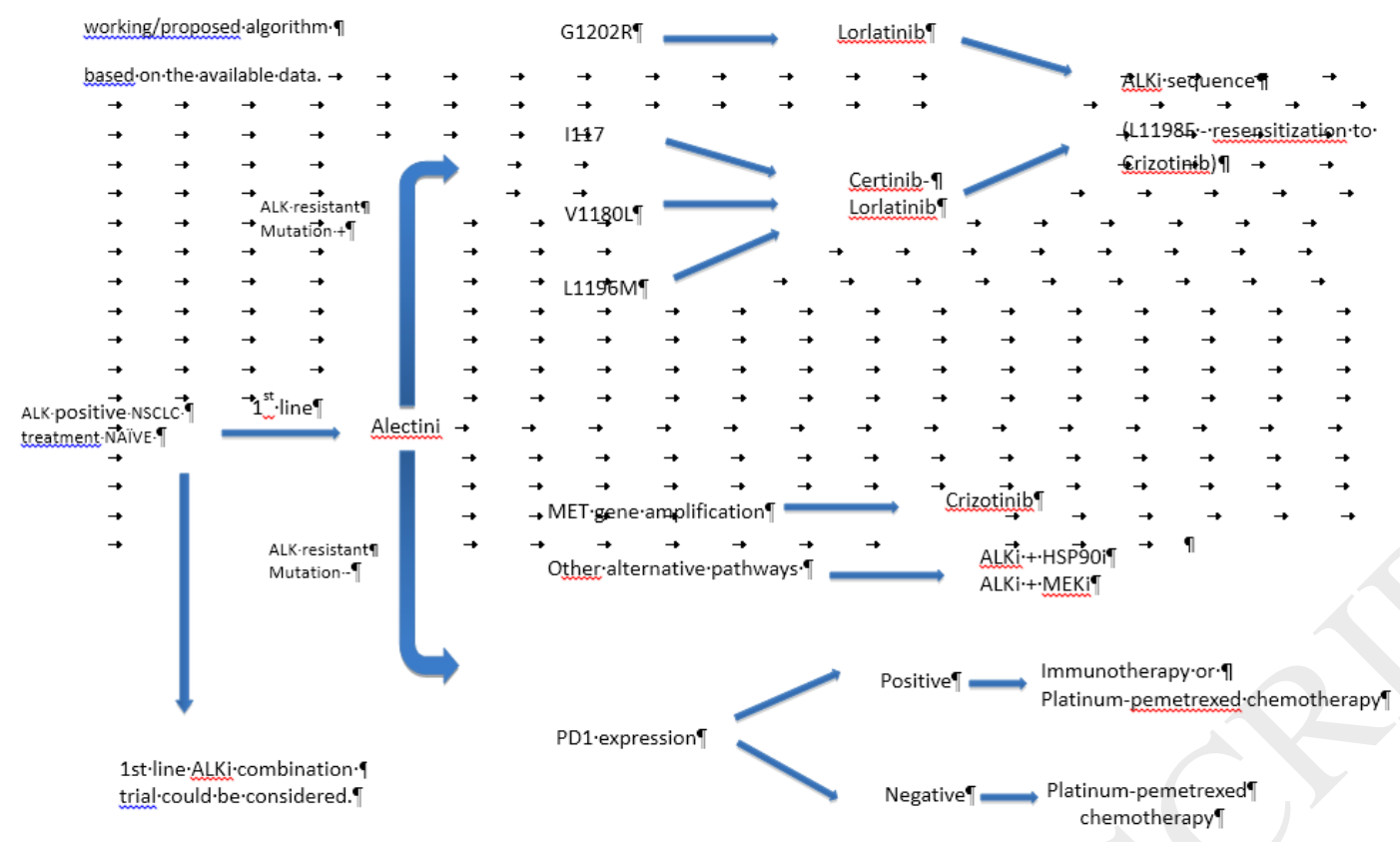

